\title{
Tanggap Pertumbuhan dan Hasil Tanaman Sawi Pagoda (Brassica norinosa) Terhadap Berbagai Dosis Nutrisi AB MIX Metode Hidroponik dengan Sistem Rakit Apung
}

\author{
Inka Dahlianah $^{1 *}$, Arwinsyah ${ }^{2}$, Pebriana K.S ${ }^{3}$, Suhal N.R ${ }^{4}$ \\ *e-mail: inkadahlianahrohim@gmail.com \\ ${ }^{1,3,4}$ Program Studi Biologi, Fakultas Matematika dan Ilmu Pengetahuan Alam \\ Universitas PGRI Palembang \\ ${ }^{2}$ Program Studi Biologi, Fakultas Matematika dan Ilmu Pengetahuan Alam \\ Universitas Sriwijaya
}

\begin{abstract}
The purpose of this research to find a suitable dose of ab mix for pagoda mustard plant, has been carried out on Jalan Sukakarya, Sukarami, Palembang. The trial was conducted in October to December 2019 who have used a perfectly randomized design method is a single factor group with 5 treatments and 4 replications. Each treatment consisted of 3 plant so there was 20 and a total of 60 plants. This was the dose of $A B$ mix fertilizer (D), namely D1 $=850 \mathrm{ppm}, \mathrm{D} 2=1050 \mathrm{ppm}, \mathrm{D} 3=1250 \mathrm{ppm}, \mathrm{D} 4=$ $1450 \mathrm{ppm}$, and D5 $=1650 \mathrm{ppm}$. The observed parameters were plant height, root length, and wet basis, measured at the end of the study. The results showed that the highest yield of D3 treatment was obtained at root length and plant wet basis respectively of $15.77 \mathrm{~cm}$ and $149.97 \mathrm{~g}$ and the highest yield of D4 treatment was obtained on plant height parameters of $12.91 \mathrm{~cm}$, and the lowest yield was very significant in D5 respectively $9.24 \mathrm{~cm}, 9.57 \mathrm{~cm}$ and $112.50 \mathrm{~cm}$.
\end{abstract}

Keywords: Pagoda Mustard, Dose, Plant, Single factor, AB mix

\begin{abstract}
ABSTRAK
Pemberian AB Mix bertujuan untuk mengetahui takaran yang tepat. Penelitian telah dilakukan dilahan pekarangan jalan Sukakarya, Sukarami Palembang dari bulan Oktober-Desember 2019. Metode yang di pakai adalah Rancangan acak lengkap (RAL) monofaktor. Jumlah tanaman keseluruhan berjumlah 60 dari 5 perlakuan dan 4 ulangan, sehingga diperoleh 20 unit. Satuan perlakuan terdapat 3 tanaman. Faktor dosis $\mathrm{AB}$ mix (D) yaitu $\mathrm{D} 1=850 \mathrm{ppm}, \mathrm{D} 2=1050 \mathrm{ppm}, \mathrm{D} 3=1250 \mathrm{ppm}, \mathrm{D} 4=1450$ ppm, dan D5 $=1650 \mathrm{ppm}$. Peubah yang diamati adalah faktor pertumbuhan tanaman yaitu tinggi tanaman $(\mathrm{cm})$, panjang akar $(\mathrm{cm})$, dan berat basah $(\mathrm{g})$. Hasil yang diperoleh menunjukkan bahwa perlakuan D3 tertinggi terdapat pada peubah panjang akar dan berat basah tanaman berturut-turut sebesar 15,77 $\mathrm{cm}$ dan 149,97 $\mathrm{g}$ dan perlakuan D4 produksi tertinggi diperoleh pada tinggi tanaman sebesar $12,91 \mathrm{~cm}$, hasil terendah pada ketiga peubah yaitu sebesar $09,57 \mathrm{~cm}, 112,50 \mathrm{~g}$ dan $09,24 \mathrm{~cm}$, pada perlakuan D5 memperlihatkan perbedaan yang sangat jauh dibandingkan perlakuan lain.
\end{abstract}

Kata Kunci: Sawi Pagoda, Dosis, Tanaman, Monofaktor, AB Mix 


\section{PENDAHULUAN}

Tanaman sawi pagoda memiliki daun berwarna hijau pekat, banyak mengandung vitamin, mineral, dan serat. Sesuai dengan pendapat Balitbangtan, (2018) bahwa sayuran berwarna mengandung zat-zat penting didalamnya yang sangat bermanfaat bagi kesehatan dan pemenuhan nilai gizi bila dikonsumsi. Lebih lanjut menurut Wikipedia, (2020) bahwa tanaman ini berasal dari tiongkok yang lebih dikenal dengan nama lain ta ke chai, memiliki bentuk daun oval dengan warna yang indah dan unik.

Jenis sayuran ini tidak banyak terdapat di pasaran, berbeda dengan tanaman sawi lainnya seperti sawi caisim, dan sawi hijau. Tanaman hortikultura berupa sayuran berguna untuk memenuhi kebutuhan masyarakat luas baik untuk anak-anak maupun orang dewasa. Kebutuhan akan sayur dewasa ini semakin meningkat, karena secara kuantitas jumlah masyarakat semakin bertambah, yang tentunya berimbas pada luas lahan yang semakin terbatas. Keadaan ini mendorong untuk mencari alternatif lain untuk dapat bercocok tanam yaitu dengan sistem bertani tidak dengan secara umum, yaitu hidroponik. Bila dibandingkan budidaya secara hidroponik dengan tradisional tentu saja yang menggunakan teknologi akan memiliki beberapa kelebihan.

$$
\text { Hidroponik adalah suatu }
$$

teknologi cara bercocok tanam tanpa menggunakan tanah. Cara ini menggunakan air baku yang diberi larutan nutrisi. Kelebihan tanaman yang dihasilkan memiliki kualitas baik yang dapat dilihat dari segi warna, bentuk, ukuran dan rasa, tidak tergantung musim dapat dilakukan penanaman sesuai dengan kebutuhan pasar, hemat tenaga karena tidak perlu mengeluarkan tenaga mengolah tanah, mengendalikan gulma, melakukan pemeliharaan penyiraman pagi dan sore hari, tidak melakukan pembumbunan, menyulam bibit tanaman, dan mutu tanaman hidroponik yang dihasilkan terjaga. Sesuai dengan pendapat Hartus (2007), bahwa bercocok tanam secara hidroponik itu dilakukan ditempat yang sesuai dengan yang dibutuhkan oleh tanaman tersebut. Selain kelebihan ada beberapa kelemahan dari sistem hidoponik yaitu memerlukan investasi atau dana yang cukup besar diawal, perlu adanya keahlian khusus, keterampilan dalam meramu larutan yang harus tepat takaran, tepat waktu dan tepat cara.

Hidroponik berasal dari dua kata yaitu air atau hydro dan kerja atau ponos (Wikipedia, 2020). Teknologi sistem kerja dengan air ini merupakan bercocok tanam tanpa mengunakan tanah. Metode ini merupakan solusi bercocok tanam diarea perkotaan yang memiliki lahan yang tidak terlalu luas, seperti di perumahan, di dak atau atas rumah yang tingkat maupun didaerah pedesaan yang belum memanfaatkan teknologi dalam bercocok tanam, kegiatan ini dapat dilakukan sebagai suatu hobi, maupun untuk komersil mendapatkan pemasukan baik skala kecil maupun untuk skala besar. Menurut Nisha, et al, (2018), bahwa budidaya hidroponik adalah menumbuhkan tanaman dengan media air, atau menggunakan media lain seperti tanah gambut, serbuk gergaji, cocopeat, rockwool. Agrovermikulit, serat sabut kelapa, batu kerikil, pecahan batu bata dan lain-lain. Media ini berfungsi untuk menegakkan tanaman yang ditanam secara hidroponik. Tanaman hidroponik membutuhkan nutrisi yang langsung tersedia untuk pertumbuhannya.

Beberapa faktor penentu keberhasilan dari bertanam hidroponik adalah pemberian nutrisi yang sekaligus dapat dijadikan sebagai tolok ukur keberhasilan yaitu dengan melihat hasil 
dan kualitas hasil tanaman. Menurut Park and Murray (2011), pemberian faktorfaktor tumbuh atau larutan hara pada teknologi ini akan mempengaruhi organ tanaman secara menyeluruh.

Sistem bertanam hidroponik terdapat banyak sistem, diantaranya adalah sistem rakit apung. Penggunaan cara ini karena lebih mudah dan praktis untuk dilaksanakan. Caranya hanya dengan meletakkan tanaman di atas media air dengan bantuan styrofoam untuk tempat lubang tanam atau bisa juga menggunakan bahan lain seperti dari triplek, karton dan sebagainya.

Penelitian ini bertujuan untuk memperoleh ukuran pemberian nutrisi yang baik dan sesuai bagi pertumbuhan tanaman sawi pagoda. Berdasarkan permasalahan di atas, maka perlu diteliti pertumbuhan tanaman sawi ( $B$ norinosa) berbagai dosis yang tepat dengan teknologi hidroponik.

\section{BAHAN DAN METODE}

Studi telah dilaksanakan di bulan Oktober-Desember 2019 di lahan pekarangan Jl sukakarya Sukarami Palembang Sumatera Selatan. Peralatan yang digunakan adalah styrofoam, tray semai, pisau, gunting, cutter, pembolong Styrofoam, TDS meter, $\mathrm{pH}$ meter, aerator, baskom plastik, gelas ukur, pinset. Bahan yang digunakan benih sawi, air baku, styrofoam, bambu, rockwool, plastik UV. Sistem dilakukan dengan disain secara lengkap (RAL) yaitu $\mathrm{D} 1=850 \mathrm{ppm}, \mathrm{D} 2=1050 \mathrm{ppm}, \mathrm{D} 3=$ 1250 ppm, D4= 1450 ppm D5=1650

Tabel 1. Hasil Analisis Keragaman Tanggap Pertumbuhan Tanaman Sawi Pagoda (Brassica norinora) terhadap berbagai Dosis Nutrisi AB Mix Metode Hidroponik dengan sistem Rakit Apung.

\begin{tabular}{|c|c|c|}
\hline Peubah yang diamati & Dosis Nutrisi Hidroponik & KK (\%) \\
\hline Tinggi Tanaman & $* *$ & 4,80 \\
\hline Panjang Akar & $* *$ & 5,00 \\
\hline Berat Basah & $* *$ & 6,90 \\
\hline
\end{tabular}

ppm, dengan faktor tunggal, dengan 5 perlakuan dan 4 ulangan, sehingga terdapat 20, setiap unit 3 tanaman, dan jumlah keseluruhan menjadi 60 (Gomez and Gomez, 1978).

Peubah yang diamati adalah tinggi tanaman $(\mathrm{cm})$, panjang akar $(\mathrm{cm})$ dan berat basah tanaman $(\mathrm{g})$ yang diukur pada priode akhir penelitian.

Persemaian disiapkan dalam tray semai dengan menggunakan media rockwool, potong rockwoll kemudian dibasahi dengan air. Selanjutnya masukkan benih sawi kelubang tanam sebanyak 1 biji perlubang tanam.

Pembuatan pupuk AB Mix dilakukan dengan membuat 2 macam pekatan yaitu pekatan A dan Pekatan B, ambil nutrisi sesuai perlakuan kemudian dilarutkan kedalam 5 liter air. Pupuk pekatan A dan B tidak boleh dicampur pupuk ini sebagai stok. Ketika membuat larutan untuk masing-masing perlakuan maka pekatan A dan B baru bisa dicampurkan.

\section{HASIL DAN PEMBAHASAN}

Pemberian nutrisi hidroponik terlihat memberi pengaruh sangat nyata terhadap varibel yang diamati pada tabel 1. Dari tabel 1. Terlihat bahwa semua peubah berpengaruh sangat nyata terhadap pemberian dosis nutrisi hidroponik. Hasil Uji beda Nyata terkecil perlakuan terhadap peubah yang diamati terdapat pada tabel 2 . 
Terlihat pada tabel 2 Hasil uji beda nyata terkecil terdapat peningkatan pada perlakuan D1 sampai D4 dan mengalami penurunan pada semua peubah pada perlakuan D5 secara signifikan, sedangkan panjang akar dan berat basah terjadi penurunan pada perlakuan D4. Pada perlakuan .D1 sampai D4 yang diberikan diduga masih berada pada rentang pemberian yang baik, sehingga tanaman memperlihatkan pertumbuhan yang maksimal hijau dan subur. Penurunan secara signifikan pada D5 ini, bahwa tanaman sudah menunjukkan gejala defiensi dan toksisitas akan unsur hara yang diberikan. Tanaman sebagai suatu organisme menunjukkan batas toleransi maksimal dan minimal tehadap unsur hara yang diberikan, tidak berlebihan dan tidak boleh kekurangan artinya harus berada pada rentang yang sesuai bagi tiap- tiap jenis tanaman. Bila keadaan tidak berada pada yang dibutuhkan suatu tanaman, maka tanaman akan secara visual memperlihatkan gejala tersebut yaitu secara morfologi pada daun yang menguning, batang yang kecil dan sebagainya. Pada perlakuan D5 yaitu1650 ppm sudah melebih dari yang dibutuhkan oleh tanaman maka respon defisiensi dan toksisitas terlihat pada keseluruhan peubah hasil sangat rendah dengan daun yang terlihat terbakar, dan juga akar yang kurang bagus.

Tabel 2. Hasil Uji BNT terhadap Peubah yang diamati

\begin{tabular}{|l|l|l|l|}
\hline Dosis & Tinggi Tanaman $(\mathrm{cm})$ & Panjang Akar $(\mathrm{cm})$ & Berat Basah $(\mathrm{g})$ \\
\hline D1: 850 PPM & $10,00 \mathrm{a}$ & $14,08 \mathrm{~b}$ & $131.37 \mathrm{~b}$ \\
\hline D2: 1050 PPM & $10,24 \mathrm{~b}$ & $15,30 \mathrm{~cd}$ & $132,50 \mathrm{~b}$ \\
\hline D3: 1250 PPM & $11,87 \mathrm{bc}$ & $15,77 \mathrm{~d}$ & $149.97 \mathrm{~d}$ \\
\hline D4: 1450 PPM & $12,91 \mathrm{~d}$ & $15,00 \mathrm{bc}$ & $145,83 \mathrm{bc}$ \\
\hline D4: 1450 PPM & $09,24 \mathrm{a}$ & $09,57 \mathrm{a}$ & $112,50 \mathrm{a}$ \\
\hline
\end{tabular}

Keterangan: Berdasarkan uji BNT pada taraf $5 \%$ angka-angka yang diikuti huruf yang sama berarti berbeda tidak nyata.

Perlakuan D3 1250 ppm dan D4 1450 ppm merupakan ukuran yang terbaik. Menurut Dahlianah (2014), bahwa pemupukan merupakan upaya peningkatan pertumbuhan dan produksi tanaman dengan mencukupi kebutuhan hara selama siklus hidupnya. Selain itu pengaplikasian ini dapat menunjang pertumbuhan tanaman sawi pagoda secara optimal. Diduga bahwa $1250 \mathrm{ppm}$ dan $1450 \mathrm{ppm}$ merupakan dosis nutrisi yang tersedia bagi tanaman. Lebih lanjut bahwa unsur hara yang terkandung pada pupuk $\mathrm{AB}$ mix baik makro maupun mikro dapat membantu tumbuhnya tanaman dengan baik sehingga melancarkan proses pengubahan $\mathrm{CO}_{2}$ dan air menjadi karbohidrat dan air, yang akhirnya dapat meningkatkan pembentukan asimllat/fotosintat bagi tanaman, hasil ini akan disalurkan pada panjang akar dan berat basah tanaman dan tinggi tanaman yang lebih tinggi dibandingkan perlakuan lain, yang diperlihatkan pada tanaman yang sehat hijau pekat, subur dengan akar yang putih artinya penyerapan oksigen juga sangat baik. Sesuai dengan pendapat Dewi et al, tanaman akan meningkat pertumbuhannya bila zat makanan berada dalam keadaan yang cukup dan seimbang bagi tanaman.

Penelitian dengan berbagai dosis pupuk terhadap tanaman sawi pagoda ini diharapkan akan mendapatkan takaran yang cocok bagi tanaman sawi, guna memperoleh pertumbuhan tanaman sawi yang berkualitas, dapat dilihat dari tinggi tanaman, panjang akar, dan berat basah yang dihasilkan. Sesuai dengan pendapat 
mas'ud (2001), bahwa variasi takaran pemupukan adalah suatu cara untuk mendapatkan dosis yang sesuai dengan masing-masing jenis tanaman.

Tinggi tanaman yang tertinggi diperoleh pada 1450 ppm sebesar 12,91 $\mathrm{cm}$, disebabkan proses pembelahan dan perpanjangan sel secara maksimal akibatnya pertambahan tinggi akan terjadi. Sesuai dengan pendapat Lakitan (2007), bahwa proses kegiatan sel yang terdapat dalam tubuh tanaman memerlukan zat makanan untuk kelancaran dalam kegiatannya.

Pada panjang akar yang tertinggi diperoleh pada 1250 ppm yaitu sebesar $15,77 \mathrm{~cm}$, diduga bahwa proses penyerapan nutrisi oleh akar akan berjalan dengan baik dengan angka ppm ini. Hal ini berhubungan erat dengan oksigen yang berada dalam keadaan yang cukup, sehingga proses aerasi akar akan berjalan dengan baik dengan diperlihatkannya akar yang lebih panjang dan lebih putih. Aerasi yang baik akan berpengaruh terhadap perkembangan akar terutama sel-sel akar yang selanjutnya akan membantu proses penyerapan nutrisi yang baik oleh akar.

Berat basah tertinggi diperoleh pada D3 1250 ppm sebesar 149,97 g, bahwa ada hubungan kegiatan utama tanaman dengan berat basah. Tanaman sebagai produsen melaksanakan aktivitasnya dengan lancar yang akhirnya menghasilkan glukosa, oksigen dan air dengan sangat baik dan jaringan sumber akan mensuplai zat makanan tersebut ke jaringan penampung berupa berat basah tanaman sehingga perlakuan D3 lebih berat dibandingkan perlakuan lain. Sesuai dengan pendapat Egli (1999) bahwa, Pertumbuhan dan hasil tanaman dipengaruhi oleh proses kegiatan fotosintesa yang menghasilkan fotosintat, jaringan atau source mensuplai kemudian mentranslokasikan melalui berkas pengangkut ke seluruh jaringan tanaman yang membutuhkan yaitu sink. Lebih lanjut menurut pendapat Lakitan (2007, ) bahwa produk yang dihasilkan oleh tanaman berupa fotosintat akan disebar keseluruh bagian tanaman pada siklus tumbuhnya.

\section{KESIMPULAN}

Kesimpulan dari hasil penelitian disimpulkan adalah Pupuk ab mix pada perlakuan D4 1450 ppm menunjukkan nilai paling tinggi pada tinggi tanaman sebesar 12,91 cm, perlakuan D3 1250 ppm tertinggi terdapat pada panjang akar sebesar 15,77 cm, dan berat basah tanaman sebesar 149,97 g. Pada perlakuan D5 1650 ppm menunjukkan hasil terendah pada parameter tinggi tanaman sebesar 9,24 cm, panjang akar sebesar 9,57 cm dan berat basah tanaman sebesar $112,50 \mathrm{~g}$.

\section{DAFTAR PUSTAKA}

Balitbangtan. (2018). Laporan Kinerja Balitbangtan 2018. Balai Penelitian dan Pengembangan Kementerian Pertanian.

Dahlianah, I. (2014). Pupuk Organik Pengaruhnya Terhadap Tanaman dan Lingkungan Tanah. Jurnal Klorofil, 9(1) .

Dewi, P., \& Jumini. (2012). Pertumbuhan dan Hasil Dua Varietas Tomat Akibat Perlakuan Jenis Pupuk. Jurnal Floratek, 76-84.

Egli, D. B. (1999). Vaariation in Leaf Starch and Sink Limitation During Seed Filling in Soybean. Crop Science.

Gomez, K. A., \& Gomez, A. (1978). Statistical Procedur for Agricultural Research. New York: John Weley \& Sons.

Hartus. (2007). Berkebun Hidroponik secara Murah. Jakarta: Penerbit Swadaya.

Hidayati, M. (2009). Sistem Hidroponik dengan Nutrisi dan Media 
Tanggap Pertumbuhan dan ...,...Inka D., Febriana K. S., Suhal N. R,...Sainmatika,...Volume 17,...No.1,...Juni 2020,...5560

Tanaman Berbeda Terhadap Pertumbuhan dan Hasil Selada. Palu: Program Studi Budidaya Pertanian Universitas Tadulako.

Lakitan, B. (2007). Dasar -Dasar Fisiologi Tumbuhan. Jakarta: PT. Raja Grafindo Persada.

Sharma, N., Acharya, S., Kumar, K., Singh, N., \& Chaurasia, O. P. (2018). Hydroponic as an Advanced Technique for Vegetable Production : An Overview. Journal of Soil and Water Conservation, 17 (4) , 364-371.

Sophie, P., \& Carly, M. (2011). Leafy Asean Vegetables and Their Nutrion in Hydroponics State of New South Wales Through the Department of Industry and Investment NSW Australian. Australia: Industry and Investment NSW .

Wikipedia. (t.thn.). Dipetik Januari 5, 2020, dari https://id.wikipedia.org/wiki/Sawi_ pagoda

Wikipedia. (2019). Dipetik Februari 20, 2019 , dari https://id.wikipedia.org/wiki/Hidro ponik 